\title{
Угольные ресурсы Кузбасса как фактор выбора стратегии развития отрасли
}

А.И. копытов, доктор технических наук, руководитель Сибирского отделения АГН, КузГТУ им. Т.Ф. Горбачева. E-mail: L01BDV@yandex.ru С.В. ШАКЛЕИН, доктор технических наук, Кемеровский филиал Института вычислительных технологий СО РАН и Федеральный исследовательский центр угля и углехимии СО РАН, Кемерово. E-mail: svs1950@mail.ru

Показано, что развитие открытой добычи угля, прежде всего коксующегося, ограничено горизонтом 20-30 лет, и для увеличения объёмов добычи необходима разработка новых технологий подземной добычи, ориентированных на освоение запасов, рассматриваемых ныне как низкотехнологичные. По мнению авторов, программа развития угледобычи должна включать в себя оценку «экологической угледобывающей емкости» региона а) по степени влияния действующих предприятий и б) по последствиям, возникающим после их ликвидации (закрытия). Для стимулирования недропользователей к инновационному решению технолого-экологических проблем предлагается перейти к преимущественному использованию в регионе конкурсной формы предоставления права пользования недрами, при включении в условия конкурса требований по разработке и реализации новых технологий добычи.

Ключевые слова: Кузбасс; стратегия развития; угольная отрасль; запасы угля; технологии добычи; экология; лицензирование

За 2000-2017 гг. объемы добычи угля в России выросли в 1,6 раза (в Кузбассе - в 2,2 раза). Этот рост был обеспечен преимущественно за счет открытого способа добычи, доля которого превысила $70 \%$.

Основную часть добычи и экспорта отечественного угля обеспечивает Кузбасс. За 2016 г. было добыто 227,4 млн т угля, из которых свыше 145 млн т - открытым способом, в 2017 г. 241,5 млн т, в том числе более 156,6 млн т открытым способом; на экспорт поставлено 140,7 млн т угля.

С начала разработки угольных месторождений из недр Кузбасса было извлечено более 10 млрд т угля, но их потенциал еще очень велик. Балансовые запасы угля бассейна по состоянию на 01.01.2016 г. составляют по категориям $\mathrm{A}+\mathrm{B}+\mathrm{C}_{1}-54,6$ млрд т (из них 19,1 млрд т - в распределенном фонде недр), по категории $\mathrm{C}_{2}-14,7$ млрд т. Для открытой отработки пригодно 11,9 млрд т запасов категорий $\mathrm{A}+\mathrm{B}+\mathrm{C}_{1}$ и 6,4 млрд т категории $\mathrm{C}_{2}$, из них коксующихся углей, соответственно, 2,8 и 1,2 млрд т. Общее количе- 
ство прогнозных ресурсов угля $\left(\mathrm{P}_{1}+\mathrm{P}_{2}\right)$ на 01.10.2015 г. составляет 305 млрд т ${ }^{1}$.

Однако динамика количества балансовых запасов (рисунок) связана не столько с добычей и сопутствующими ей потерями, сколько с изменением оценки их технологической значимости.

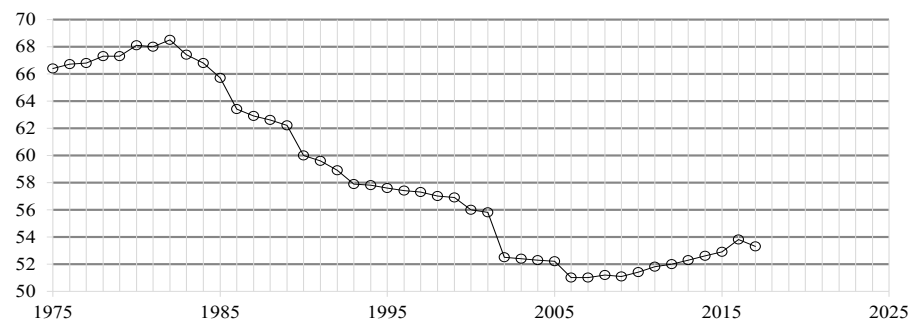

Источник: данные государственных балансов запасов полезных ископаемых за 1975-2017 годы.

Изменение количества балансовых запасов угля Кузбасса категорий $\mathrm{A}+\mathrm{B}+\mathrm{C}_{1}$ расположенных в границах Кемеровской области в 1975-2025 гг., млрд т

Так, в период с 1983 по 2007 гг., при среднегодовой добыче угля около 130 млн т ежегодное снижение балансовых запасов составляло в среднем более 700 млн т. Это было вызвано тем, что основная часть числящихся на государственном балансе запасов была поставлена на учет по результатам разведок 1950-1980х гг, которые уже не в полной мере соответствуют современным требованиям промышленности к горно-геологическим условиям отработки. В ходе разведочных работ («расчисток») и при исчерпании предприятиями технологически привлекательных запасов с баланса постоянно списывается значительное количество угля. В рамках реализации программы ликвидации убыточных шахт в скором будущем в городах Прокопьевск и Киселевск будут ликвидированы шахты, у которых имеется почти 614 млн т балансовых запасов коксующихся углей.

При оценке реальной ресурсной базы не учитывается тот факт, что, как правило, участки недр с низкометаморфизованным энергетическим углем востребуются промышленностью для подземной добычи только в том случае, если по сложности геологического

\footnotetext{
${ }^{1}$ Программа лицензирования угольных месторождений на период до 2020 года: утверждена приказом Минприроды России от 06.12.2016 № 639. 63 с.
} 
строения они относятся к первой группе [Шаклеин, Писаренко, 2014]. Участки второй группы сложности интересуют недропользователей лишь а) при наличии на них коксующихся углей, б) если речь идет о высокометаморфизованных энергетических углях, имеющих высокие устойчивый спрос и стоимость. Участки третьей группы сложности востребуются только для организации открытой добычи. Кроме того, отметим, что реально подлежащие извлечению запасы действующих предприятий, как правило, оцениваются ими примерно на $30-40 \%$ ниже, чем это указывается в отчетной документации. Поэтому оценка Минприроды РФ обеспеченности действующих предприятий Кузбасса промышленными запасами угля (для шахт -47 лет, а для разрезов -30 лет) $)^{2}$, представляется явно завылиенной.

Отмеченный на рисунке рост с 2010 г. балансовых запасов угля в Кузбассе обеспечивается геологоразведочными работами по новым лицензированным участкам недр, минерально-сырьевая база которых ранее не учитывалась на государственном балансе, так как была представлена преимущественно прогнозными ресурсами. Всего с 2004 г. по настоящее время в освоение было передано 3,824 млрд т прогнозных ресурсов угля (в том числе 3,167 млрд т категории $\mathrm{P}_{1}$ и 657 млрд т категории $\mathrm{P}_{2}$ ). Однако тот факт, что компании, при наличии обширного фонда разведанных участков недр, предпочли получить право пользования неразведанными, свидетельствует о низкой привлекательности значимой части числящихся на государственном учете запасов Кузбасса. Это признают и органы госуправления. Так, в рамках госконтракта № 9/2013 ООО «Недра Кузбасса» в 2015 г. выполнило работу «Анализ и оценка состояния угольной сырьевой базы Кузнецкого бассейна с разработкой предложений по рациональному использованию недр». Госзаказчик предпочел не доводить ее результаты до сведения промышленности.

Сегодня вполне очевидно, что использование существующего комплекса технологий угледобычи, ориентированного на достаточно узкий спектр горно-геологических условий, ведет к ускоренному исчерпанию разведанных запасов. По мнению авторов, в этих условиях стратегия освоения Кузнецкого бассейна должна

2 Программа лицензирования угольных месторождений на период до 2020 года: утверждена приказом Минприроды России от 06.12.2016 № 639. 63 с. 
заключаться в переходе от поиска участков недр с заданныли горно-геологическими условиями к поиску и разработке технологий добычи и обогащчения, обеспечивающих вовлечение в оборот ранее невостребованных запасов [Шаклеин, Писаренко, 2014]. Такой подход создает объективные предпосылки к переходу на интенсивный путь развития минерально-сырьевой базы, наиболее подходящий к условиям освоенных промышленностью районов, к которым относится и Кузбасс. Он не только позволяет эффективно использовать имеющийся промышленный потенциал, инфраструктуру, трудовые ресурсы, но и стимулирует развитие горной науки и техники.

Не секрет, что отечественным производителям сегодня сложно достигнуть мирового уровня качества массового горношахтного оборудования. Разработка и выпуск машин для отработки сложных месторождений может стать для них хорошей альтернативой, а в перспективе - и выгодной статьей экспорта. Подчеркнем, что предлагаемый путь развития невозможен без воссоздания отраслевой науки и организации частного или государственного научно-технологического центра, имеющего в своем составе НИИ, инжиниринговый центр промышленных технологий, центры опытного производства и испытаний.

Необходимость достижения принципиально нового уровня технологического обеспечения подземной добычи вытекает и из состояния минерально-сырьевой базы бассейна, и из тенденции к повышению доли потребления коксующихся углей в мире. На долю коксующихся углей приходится 48\% запасов бассейна (32,8 млрд т, в том числе категорий $\mathrm{A}+\mathrm{B}+\mathrm{C}_{1}-28,5$ млрд т), а на долю особо ценных марок (ГЖ, Ж, КЖ, К, ОС) - 28\% (15,1 млрд т, в том числе категорий $\mathrm{A}+\mathrm{B}+\mathrm{C}_{1}-13,4$ млрд т). Но для открытой отработки пригодны только 3,928 млрд т коксующихся углей и всего 0,6 млрд т - запасов ценных марок, большая часть которых уже осваивается или намечена к ускоренному освоению.

Таким образом, сохранить роль Кузбасса как поставщика коксующихся углей в перспективе невозможно без увеличения объемов подземной добычи. В настоящее время здесь наблюдается «эра» открытой добычи, которая, по нашей оценке, закончится через 20-30 лет. Именно за этот небольшой период и необходимо создать новые технологии подземной добычи. Однако Программа развития угольной промышленности данный аспект отраслевого развития не рассматривает. 
По мнению авторов, эффективным стимулом к инновационному поведению недропользователей может стать конкурсная процедура предоставления лицензии, в условия которой должны войти требования по разработке и внедрению новых технологий добычи, ориентированных на извлечение низкотехнологичных запасов угля. Для формирования реального представления о состоянии минерально-сырьевой базы целесообразно на правовом уровне закрепить ныне используемое научно-техническое понятие «высокотехнологичные запасы» и использовать его при ведении государственного баланса.

Отметим, что увеличение объемов открытой добычи угля привело к росту социальной напряженности в Кемеровской области. Дело в том, что в отсутствие генеральной схемы освоения месторождений Кузбасса строящиеся разрезы нередко размещаются в непосредственной близости к уже действующим, нарастают уровень и темпы изъятия земель под разрезы и отвалы.

Исходя из того, что на 1 млн т добываемого угля разрушается не менее 6 га поверхности [Геоэкология, 2005], можно предположить, что при сохранении нынешней динамики угледобычи, ежегодно будет нарушаться около 1200 га земель. Очевидно, что именно открытый способ добычи угля является главной экологической угрозой: ведет к нарушению природных территорий, сокращению биоразнообразия, ухудшению состояния окружающей среды и повышению сейсмической активности. Так, в июне 2013 г. на борту «Бачатского» угольного разреза произошло одно из сильнейших техногенных землетрясений (семь баллов по шкале MSK-84). В пяти-шестибалльную зону попали города Ленинск-Кузнецкий, Белово, Полысаево, Гурьевск и др. Землетрясение ощущалось и в соседних регионах [Техногенная, 2014].

Тем не менее общепризнанное понимание существования экологических ограничений на добычу угля в Кузбассе до сих пор не получило научно обоснованного количественного выражения. Необходимость решения данного вопроса вышеупомянутой Программой развития отрасли не оговаривается [Копытов и др., 2017].

Недостаточное внимание Программа уделяет и вопросу ликвидации горных предприятий, который, по мнению авторов, должен решаться, прежде всего, с позиции экологии. После завершения отработки карьерные выемки разрезов, как правило, затопляются, а шахты - заполняются грунтовыми водами, в результате чего 
нередко возникают зоны обширного подтопления территорий, в том числе - населенных пунктов. Так, по результатам инструментальных наблюдений 1980-х годов, выполненных экспедицией № 142 ГУГК, оседание земной поверхности в районе г. ЛенинскКузнецкий относительно первоначального уровня достигает 10 м.

Предлагаемое Минприродой создание на всех горных предприятиях ликвидационных фондов не решает проблемы и не приводит к возможности их «сухой» ликвидации, ведь после закрытия шахт и разрезов «исчезает» и источник их финансирования. Да, такие фонды необходимы, но они должны создаваться за счет средств предприятий при субъектах Федерации, которые непосредственно заинтересованы в экологическом благополучии территории. Кроме того, на наш взгляд, средства этих фондов должны «работать», обеспечивая своей прибылью финансирование постоянно действующих мероприятий по откачке воды, ликвидации последствий обрушения и т.д., а также опережающей (по отношению к развитию горных работ) рекультивации нарушенных территорий.

По мнению авторов, «экологическая угледобывающая емкость» региона должна определяться по двум направлениям. Первое из них (и основное сегодня) заключается в учете ограниченного во времени воздействия работающих предприятий на природную среду (загрязнение водного и воздушного бассейнов, почвы, уменьшение площади водосбора, сокращение или исчезновение гидрографической сети, изменение или даже разрыв взаимосвязи стока реки с подземными стоками, деградация биоценозов и т.д.). Второе направление состоит в оценке того, как изменится природная среда после завершения деятельности предприятий.

Очевидна методологическая неопределенность такой оценки, вызванная нерешенностью проблем прогнозирования а) климатических изменений в результате появления многочисленных рукотворных озер, б) изменений напряженно-деформированного состояния массивов горных пород в районе затопленных карьеров, в) влияния на окружающую среду необратимых изменений геомеханического состояния горных пород, вызванных подземными горными работами (объем нарушенного подземного пространства уже превышает в Кузбассе 150 млрд м $^{3}$ ) и пр. Кроме того, по условиям современных лицензий на право пользования недрами, проект ликвидации горных выработок, скважин, иных подземных сооружений должен выполняться на последней стадии 
работы предприятия - не позднее, чем за один год до планируемого срока завершения отработки участка недр. Однако оценить последствия деятельности предприятия, например, в части возможного подтопления территории, можно только при наличии проектных решений по ликвидации. Таким образом, с позиции оценки «экологической угледобывающей емкости» региона, необходимо, чтобы механизм ликвидацуии и оценка ее последствий содержались уже в проектной документации. Без внесения соответствующих изменений в нормативную базу недропользования такая оценка по рассматриваемому направлению невозможна.

Анализ состояния минерально-сырьевой базы Кузбасса показывает, что наблюдаемый в регионе рост открытой добычи угля, прежде всего коксующегося, - явление временное. Для сохранения достигнутых и прогнозирумых объёмов добычи необходимо предусмотреть в программе развития отрасли выполнение комплекса работ по созданию и внедрению новых технологий подземной добычи, ориентированных на освоение низкотехнологичных запасов. Помимо этого программа должна включать в себя оценку «экологической угледобывающей емкости» региона по двум направлениям: по ограниченному во времени уровню экологического влияния действующих предприятий и по постоянно действующим последствиям, возникающим после их ликвидации. Для стимулирования недропользователей к технологическим и экологическим инновациям предлагается перейти к преимущественному использованию в регионе конкурсной формы предоставления права пользования недрами. В условия конкурса должны быть включены требования по разработке и внедрению новых технологий добычи, использования и переработки угля.

\section{Литература}

Ковалев В.Н., Копьтов А.И., Першин В.В. Минерально-сырьевые ресурсы - важный потенциал инновационного развития угольно-металлургического комплекса Кузбасса // Уголь. 2014. № 2. С. 6-9. URL: http://www.ugolinfo.ru/ Free/022014.pdf (дата обращения: 16.10.2018).

Шаклеин С. В., Писаренко М.В. Концепция развития сырьевой базы Кузнецкого угольного бассейна // Физико-технические проблемы разработки полезных ископаемых. 2014. № 3. С. 118-125.

Геоэкология угледобывающих районов Кузбасса / В. П. Потапов, В. П. Мазикин, Е. Л. Счастливцев, Н. Ю. Вашлаева. Новосибирск: Наука, 2005. 660 с.

Техногенная сейсмичность разрезов Кузбасса (Бачатское землетрясение 18 июня 2013 г., ML=6,1) / А.Ф. Еманов, А.А. Еманов, А. В. Фатеев и др. // Физико-технические проблемы разработки полезных ископаемых. 2014. № 2. С. 59-67.

Копытов А.И., Манаков Ю.А., Куприянов А.Н. Развитие угледобычи и проблемы сохранения экосистем в Кузбассе // Уголь. 2017. № 3. C. 72-77. URL: http://www.ugolinfo.ru/Free/032017.pdf (дата обращения: 16.10.2018).

Статья поступила 08.10.2018. 


\section{Summary}

Kopytov A. I., Academy of Mining Sciences, T.F. Gorbachev Kuzbass State Technical University, SB RAS

Shaklein S.V., Institute of Computational Technologies, SB RAS, Federal Research Center of Coal and Coal Chemistry, SB RAS, Kemerovo

Coal Resources of Kuzbass as a Factor in the Choice of Industry Development Strategy

The authors show that the development of open-cast coal, primarily coking, mining is delimited by a horizon period of 20-30 years, and in order to increase production, it is necessary to develop new underground mining technologies, oriented towards the development of reserves, which are now considered low-tech. According to the authors, the coal mining development program should include an assessment of the "ecological coal-mining capacity" of the region a) according to the degree of influence of existing enterprises and b) the consequences arising after their abandonment (closure). In order to stimulate mineral developers to an innovative solution of technological and environmental problems, it is proposed to switch to preferential use of a competitive form of granting the right to use mineral resources in the region, with the inclusion of requirements for the development and implementation of new mining technologies in the competitive conditions.

Kuzbass; development strategy; coal industry; coal reserves; mining technologies; ecology; licensing

\section{References}

Kovalev V.N., Kopytov A.I., Pershin V.V. (2014). Mineral'no-syr'evye resursy vazhnyj potencial innovacionnogo razvitiya ugol'no-metallurgicheskogo kompleksa Kuzbassa. Ugol' (Russian Coal Journal). No.2, Pp. 6-9 (In Russ.) Available at: http://www.ugolinfo.ru/Free/022014.pdf (accessed 16.10.2018)

Shaklein S. V., Pisarenko M.V. (2014). Concept of Mineral and Raw Material Base Development in the Kuznetsk Coal Basin. Journal of Mining Science. V.50, No.3. Pp. 527-532. DOI: 10.1134/S1062739114030144.

Potapov V.P., Mazikin V.P., Schastlivtsev E.L., Vashlaeva N. Yu. (2005). Geoehkologiya ugledobyvayushchih rajonov Kuzbassa. Novosibirsk, Nauka Publ. 60 p. (In Russ.)

Emanov A. F., Emanov A.A., Fateev A. V. (2014). Tekhnogennaya sejsmichnost' razrezov Kuzbassa (Bachatskoe zemletryasenie 18 iyunya 2013 g., ML=6,1). Fizikotekhnicheskie problemy razrabotki poleznyh iskopaemyh [Journal of Mining Science]. No. 2. Pp. 59-67. (In Russ.)

Kopytov A. I., Manakov Yu.A., Kupriyanov A. N. (2017). Razvitie ugledobychi i problemy sohraneniya ehkosistem v Kuzbasse. Ugol' (Russian Coal Journal). No.3. Pp. 72-77. (In Russ.) Available at: www.ugolinfo.ru/Free/032017.pdf (accessed 16.10.2018). DOI: http://dx.doi.org/10.18796/0041-5790-2017-3-72-77. 